\title{
Comparative effects of temperature on suspension feeding and energy budgets of the pearl oysters Pinctada margaritifera and $P$. maxima
}

\author{
H. Yukihira ${ }^{1}$, J. S. Lucas $^{2, *}$, D. W. Klumpp ${ }^{3}$ \\ ${ }^{1}$ Department of Zoology and Tropical Ecology, School of Biological Sciences, James Cook University, Townsville, \\ Queensland 4811, Australia \\ ${ }^{2}$ School of Marine Biology and Aquaculture, James Cook University, Townsville, Queensland 4811, Australia \\ ${ }^{3}$ Australian Institute of Marine Science, PMB 3, Townsville MC, Queensland 4810, Australia
}

\begin{abstract}
This study assessed the effects of seasonal temperatures on suspension feeding, related physiological parameters and energy budgets in 2 pearl oysters, Pinctada margaritifera and $P$. maxima. Pearl oysters that were acclimatised at approximately $19,23,28$ and $32^{\circ} \mathrm{C}$ in the field were tested in the laboratory at these temperatures. Clearance rate (CR), absorption efficiency (ae), absorbed energy (AE), respired energy ( $R E$ ), excreted energy ( $E E$ ) and the value of (AE - RE) were significantly affected by temperature. They usually increased with increasing temperature. ae, RE, EE and the value of (AE - RE) differed significantly between the pearl oyster species. P. margaritifera had a significantly higher CR than $P$. maxima at $19^{\circ} \mathrm{C}$. P. maxima had higher ae than $P$. masgaritifera at 28 and $32^{\circ} \mathrm{C}$. As a result, $P$. margaritifera had greater AE than $P$. maxima at $19^{\circ} \mathrm{C}$, but the latter species had greater AE at $32^{\circ} \mathrm{C}$. Temperature significantly affected the RE of $P$. margaritifera over a wider temperature range $\left(19\right.$ to $\left.32^{\circ} \mathrm{C}\right)$ than $P$. maxima $\left(19\right.$ to $\left.23^{\circ} \mathrm{C}\right)$. However, interspecific differences in $R E$ were only significant at $32^{\circ} \mathrm{C}$. P. maxima had significantly higher EE at $32^{\circ} \mathrm{C}$ than $P$. margaritifera, although this energy accounted for a very small portion of $\mathrm{AE}(<5 \%)$. P. maxima exceeded $P$. margaritifera in Scope for Growth $[\mathrm{SFG}=(\mathrm{AE}-\mathrm{RE})-\mathrm{EE}]$ at $32^{\circ} \mathrm{C}$, but the latter species had greater $\mathrm{SFG}$ at $19^{\circ} \mathrm{C}$. These results agree with observations of the occurrence of $P$. margaritifera at higher latitudes and lower temperature habitats. The temperature effects on suspension feeding, related physiological parameters and SFG indicate that there will be marked seasonal variations in growth in both species in environments where water temperatures vary seasonally. In bioenergetic terms, the optimum temperature ranges for these pearl oysters are approximately 23 to 28 and 23 to $32^{\circ} \mathrm{C}$ for $P$. margaritifera and P. maxima, respectively.
\end{abstract}

KEY WORDS: Pearl oyster - Temperature - Energy budget - Pinctada margaritifera - Pinctada maxima $\cdot$ Scope for Growth Physiology

\section{INTRODUCTION}

Suspension-feeding bivalves living in shallow waters often experience markedly varying ambient temperatures over short- and long-term scales. The prevailing temperatures will often influence energy gain and expenditure of these animals, because temperature is a major extrinsic factor affecting the physiological functioning of poikilothermic organisms (Widdows

·Corresponding author. E-mail: john.lucas@jcu.edu.au
\& Bayne 1971, Wieser 1973, Newell \& Branch 1980, Bayne \& Newell 1983). These effects of temperature on the physiology and energetics of suspension-feeding bivalves, especially those of commercial importance such as mussels, oysters and clams, have been well documented. Among the studies, short-term and longterm effects of temperature on metabolic cost, which is a major component of the energy flux of bivalves, have received considerable attention (reviews by Bayne et al. 1976a, Newell \& Branch 1980, Shumway 1982). Filtration and metabolic rates of suspension-feeding bi- 
valves generally increase with increasing temperature up to a certain temperature, above which they decline (e.g. reviews by Winter 1978, Shumway 1982, Griffiths \& Griffiths 1987).

There has not been a comprehensive study of the effects of temperature on feeding and energy budgets in a tropical suspension-feeding bivalve. These effects are not likely to be fundamentally different from those in temperate bivalve species, except that the optimum and tolerated temperature ranges should be elevated. As part of a wider comparative study of the feeding and energetics of 2 similar species of tropical pearl oysters (Yukihira et al. 1998a,b, 1999), we have compared the effects of temperature on these parameters.

The black-lip pearl oyster Pinctada margaritifera (L.) and silver-lip pearl oyster $P$. maxima Jameson are suspension-feeding bivalves inhabiting tropical waters. They are economically among the most important bivalve species (family Pteriidae), producing black and silver pearls, respectively. They tend to occur in different habitats: P. margaritifera in the oligotrophic waters of coral reefs and atolls, and P. maxima on sedimentary substrates adjacent to mainland islands and continents (Yukihira et al. 1998a). They also have very different geographic distributions. P. maxima is found in tropical waters of the central Indo-Pacific, from southern China (Hainan), through SE Asia, Papua New Guinea, the Solomon Islands to northern Australia, i.e. from about $19^{\circ} \mathrm{N}$ to $19-25^{\circ} \mathrm{S}$ (Gervis \& Sims 1992). P. margaritifera is not restricted to the tropics and occurs across a much wider longitudinal and latitudinal range. It occurs in the Indian and Pacific oceans, from the East Coast of Africa to the West Coast of America, as well as the eastern Mediterranean Sea and the Ryukyu Archipelago (from $30^{\circ} \mathrm{N}$ to $28^{\circ} \mathrm{S}$ ). The different distributions of these species are exemplified on the east coast of Australia: P. margaritifera occurs as far south as Moreton Bay, South Queensland (subtropical $28^{\circ} \mathrm{S}$ ), while $P$. maxima does not occur further south than Townsville, North Queensland, at $19^{\circ} \mathrm{S}$ (Hynd 1955).

Gervis \& Sims (1992) suggested that the temperature range would be similar over the geographic ranges of both pearl oyster species (about 19 to $32^{\circ} \mathrm{C}$ ). However, this does not fit with the distribution of Pinctada margaritifera into distinctly higher latitudes. Furthermore, the main regions of cultured pearl farming with this species are at relatively high latitudes, i.e. Ryukyus, Red Sea, Cook Islands and French Polynesia. In contrast, the main regions of $P$. maxima culture are at low latitudes such as the Philippines, Indonesia and northern Australia. Temperature data for the environments and culture sites of the 2 species are very sparse, and no clear pattern is evident. Culture site data for $P$. margaritifera are 17 to $30^{\circ} \mathrm{C}$ at Kabira Bay, Okinawa, Japan (Sugiyama \& Tomori 1988); 21 to $34^{\circ} \mathrm{C}$ at Dong- onab Bay, Sudan (Reed 1966); and 26 to $30^{\circ} \mathrm{C}$ at Takapoto, French Polynesia (Coeroli et al, 1984). For $P$. maxima, there are data for 1 culture site: 25 to $32^{\circ} \mathrm{C}$ at Kuri Bay, Western Australia (Pass et al. 1987).

Temperature is one of the fundamental factors influencing physiological rates, growth and mortality of pearl oysters. Most studies of temperature effects on physiological processes in pearl oysters have been on the Japanese pearl oyster Pinctada fucata martensii. Numaguchi \& Tanaka (1986) reported that spat of this species had high mortality below $12.5^{\circ} \mathrm{C}$ and at $35^{\circ} \mathrm{C}$, and that growth rate increased from 15 to $32^{\circ} \mathrm{C}$. The optimum temperature range for spat was 17.5 to $29^{\circ} \mathrm{C}$. This species has a very low metabolic rate in winter when water temperature is below $13^{\circ} \mathrm{C}$ (Kobayashi \& Tobata 1949). Miyauchi (1962) and Numaguchi (1994) found that highest clearance rates for $P$. fucata martensij occurred at 24 to $27^{\circ} \mathrm{C}$ and 25 to $28^{\circ} \mathrm{C}$, respectively. Clearance rates declined at temperatures higher than $28^{\circ} \mathrm{C}$ in summer and lower than $13^{\circ} \mathrm{C}$ in winter (Numaguchi 1994). Seki (1972) and Itoh (1976) determined respiration and ammonia excretion rates at different temperatures. Respiration rates varied seasonally with temperature. Temperature coefficients $\left(Q_{10}\right)$ for respiration rate were high, 6.4 to 7.7 , at low temperatures $\left(10\right.$ to $14^{\circ} \mathrm{C}$ ), and became more 'normal', 2.2, at high temperatures $\left(26\right.$ to $\left.30^{\circ} \mathrm{C}\right)$. However, Uemoto (1968) reported quite contrary data: $Q_{10}$ for respiration rate varied from 1.8 to 2.8 between 13 and $27^{\circ} \mathrm{C}$, and then increased to 4.2 between 27 and $30^{\circ} \mathrm{C}$. Heart rates increased with increasing temperature and reached a maximum of 93 beats $\mathrm{min}^{-1}$ at $32^{\circ} \mathrm{C}(\mathrm{Nu}$ maguchi \& Tanaka 1986).

Only one study has examined relationships between respiration rate and temperature in Pinctada margaritifera. Sugiyama \& Tomori (1988) determined the relationship between respiration rate $\left(\mathrm{R}, \mathrm{ml} \mathrm{O}_{2} \mathrm{~h}^{-1}\right.$ for standard $100 \mathrm{~g}$ whole weight animals), temperature $\left(\mathrm{T},{ }^{\circ} \mathrm{C}\right)$ and body size (whole wet weight, $W, g$ ) as $R=$ $0.00019 \times T^{3.3448} \times W^{-0.5487}$. They demonstrated that the upper temperature limit for this species was about $35^{\circ} \mathrm{C}$. No such data are available for $P$. maxima. The only data on temperature effects for this species are from Pass et al. (1987), who found that mortalities of this species following transportation to culture sites were greater at low temperature $\left(19^{\circ} \mathrm{C}\right)$ than at $29^{\circ} \mathrm{C}$.

This study considers how temperature influences the physiological processes and energy fluxes of Pinctada margaritifera and $P$. maxima. The specific aims were: (1) to quantify the physiological processes of suspension feeding, respiration, assimilation and excretion over a wide temperature range, (2) to estimate energy budgets over a wide temperature range, (3) to compare energy budget versus temperature in the 2 species, and (4) to relate the results to these species' geographic distributions and aquaculture 


\section{MATERIALS AND METHODS}

The techniques used in this study are based on those of Yukihira et al. (1998a).

Pearl oysters. Specimens of Pinctada margaritifera ( 86 to $112 \mathrm{~mm}$ shell height, $\mathrm{n}=30$ ) were obtained from a long-line culture system located at Orpheus Island Research Station, North Queensland, Australia $\left(18^{\circ}\right.$ $\left.37^{\prime} \mathrm{S}, 146^{\circ} 30^{\prime} \mathrm{E}\right)$. Hatchery-reared specimens of $P$. maxima ( 80 to $103 \mathrm{~mm}$ shell height, $\mathrm{n}=30$ ) were obtained from a long-line farm located at Hinchinbrook Channel, North Queensland ( $18^{\circ} 18^{\prime} \mathrm{S}, 146^{\circ} 06^{\prime}$ E). All oysters were kept in frames with net pockets suspended at $0.5 \mathrm{~m}$ depth beneath a pontoon in a sheltered bay at the Australian Institute of Marine Science (AIMS), North Queensland $\left(19^{\circ} 15^{\prime} \mathrm{S}, 147^{\circ} 05^{\prime} \mathrm{E}\right)$. They were acclimatised there to experimental conditions for at least $1 \mathrm{mo}$. The shells of all oysters were thoroughly cleaned of epibiota during the acclimatisation period and they were cleaned again the day before the experiment. Seawater temperatures varied from 19 to $32^{\circ} \mathrm{C}$ over the study period. Experiments were conducted in the laboratory at AIMS on 4 occasions. On each occasion the oysters were tested at approximately ambient water temperature: 19 (July 1996), 23 (April/May 1996), 28 (November 1995) and $32^{\circ} \mathrm{C}$ (December 1995). There was $<2^{\circ} \mathrm{C}$ diurnal variation and $<3^{\circ} \mathrm{C}$ variation in temperature during each month (Yukihira et al. unpubl. data), so the oysters were essentially acclimatised to the test temperatures. The 4 temperatures cover all except the extremes of the natural habitats of $P$. margaritifera and $P$. maxima (see 'Introduction'). Experimental water temperatures were kept constant $\left( \pm 0.5^{\circ} \mathrm{C}\right)$ in the laboratory using thermostat heaters and plastic bags containing ice bricks. Experimental oysters were used only once for a series of physiological measurements (filtration, absorption, respiration and excretion) on each occasion.

Shell height ( $\mathrm{SH}, \mathrm{mm}$ ), the greatest distance from the umbo to the base of a finger or growth process (Sims 1993), was recorded as the routine non-destructive measure of size for the experiments. The dry tissue weight (wt) of each experimental oyster was estimated from $\mathrm{SH}$ using the $\mathrm{SH}$-tissue weight relationship from Yukihira et al. (1998a).

Algal suspension. The oysters were fed during experiments with 5000 cells $\mathrm{ml}^{-1}$ suspensions of the phytoflagellate Isochrysis aff. galbana Tahitian (T-Iso), which was harvested during its logarithmic phase of growth. This cell concentration $\left(=0.5 \mathrm{mg}\right.$ dry wt $\mathrm{l}^{-1}$, Yukihira et al. 1998a) approximates phytoplankton concentrations of coral reef waters (e.g Oliver et al. 1995, Pouvreau et al. 1999, Yukihira et al. 1999). The calorific value of T-Iso is $20.27 \mathrm{~J} \mathrm{mg}^{-1}$ dry tissue $\mathrm{wt}$ (Yukihira et al. 1998a).
Physiological parameters and Scope for Growth. The following is a brief summary of the techniques used. Further details are reported in Yukihira et al. (1998a). Clearance rate (CR, $1 \mathrm{~h}^{-1}$, see Hildreth \& Crisp 1976 and Bayne et al. 1985) was determined using three $6 \mathrm{l}$ chambers, each with an oyster, and a fourth chamber without an oyster acted as a control. A constant flow of ca $30 \mathrm{l} \mathrm{h}^{-1}$ with $5000 \pm 1000$ cells ml$^{-1}$ T-Iso was maintained during the experiment. Concentrations of T-Iso were measured at $1 \mathrm{~h}$ intervals using a Coulter counter. CR was determined from the decrease in cell concentration through each chamber together with flow rate. For the determination of absorption efficiency (ae, \%), faeces were collected from the chambers on completion of measurements of $C R$. The percentage absorption of consumed food was determined by comparing the fraction of faeces that was lost on ashing with the fraction of food that was lost on ashing (Conover 1966). Respiration rate $\left(\mathrm{R}, \mathrm{ml} \mathrm{O}_{2} \mathrm{~h}^{-1}\right)$ was determined after Bayne et al. (1985) using oysters immediately after completion of their CR measurements. Oysters were individually placed in three $13 \mathrm{I}$ sealed chambers and a further chamber without an oyster served as a control. Water in each chamber was continuously mixed by a magnetic stirrer. Oxygen concentrations in the chambers were measured at $5 \mathrm{~min}$ intervals using a YSI dissolved oxygen meter (model 55). Thus, absorbed energy ( $\left.A E, J^{-1}\right)$, respired energy $\left(\mathrm{RE}, \mathrm{J} \mathrm{h}^{-1}\right)$, and value of $(\mathrm{AE}-\mathrm{RE})$ could be calculated for individual oysters. Ammonia excretion rate $(E, \mu g$ $\mathrm{NH}_{4}-\mathrm{N} \mathrm{h}^{-1}$ ) was measured using the phenol-hypochlorite method of Solorzano (1969). Oysters were fed with T-Iso at a concentration of $5000 \pm 1000$ cells $\mathrm{ml}^{-1}$ for at least $2 \mathrm{~h}$ in a $100 \mathrm{l}$ tank with aeration. The oysters were then placed individually into chambers with a further chamber acting as a control; each chamber contained $0.8 \mathrm{l}$ of $0.45 \mu \mathrm{m}$ filtered seawater. Scope for Growth ( $\mathrm{SFG}, \mathrm{J} \mathrm{h}^{-1}$ ), which is the energy available to an animal for growth and reproduction in sexually mature animals (Warren \& Davis 1967, Bayne et al. 1985), was determined as follows: $\mathrm{SFG}=(\mathrm{AE}-\mathrm{RE})-\mathrm{EE}$, where $\mathrm{EE}$ is the excreted energy $\left(\mathrm{J} \mathrm{h}^{-1}\right)$.

$C R, R$ and $E$ were standardised to those of a specimen of $1 \mathrm{~g}$ dry tissue wt to allow comparisons. The function/size relationships of Yukihira et al. (1998a) were used to standardise the data.

Temperature coefficient $\left(Q_{10}\right) . Q_{10}$ for each physiological parameter (CR, ae, $A E, R E$ and $E E$ ) at the 3 temperature intervals was calculated using the equation: $Q_{10}=\left(R_{2} / R_{1}\right) \exp \left[10 /\left(t_{2}-t_{1}\right)\right]$, where $R_{2}$ and $R_{1}$ were rates of reaction at temperatures $t_{2}$ and $t_{1}$, respectively (Bayne \& Newell 1983).

Data analysis. The effects of temperature and oyster species on $C R$, ae, AE, RE, the value of ( $A E-R E)$ and EE were tested by 2-factor ANOVA. Multiple compar- 
isons were conducted using the Tukey test (Zar 1996) to compare mean values of physiological parameters between all pairs of temperatures. Mean values of physiological parameters for the same temperature were compared between species using a 1-way ANOVA. Data were tested for normality and homoscedasticity before being subjected to parametric statistics.

\section{RESULTS}

\section{Clearance rate, absorption efficiency and absorbed energy}

There was a very significant effect of temperature on clearance rate (CR) in both species (Fig. 1, Table $1 ; 2$ factor ANOVA, $p<0.0001$ ). CR values were low at $19^{\circ} \mathrm{C}$ and rose sharply, with high $Q_{10}$ values, especially in Pinctada maxima, over the 19 to $23^{\circ} \mathrm{C}$ range (Table 2). CR changed little from 23 to $28^{\circ} \mathrm{C}$, with $Q_{10}$ values near 1. CR of $P$. margaritifera declined over 28 to $32^{\circ} \mathrm{C}\left(Q_{10}=\right.$ 0.71 ) but under these conditions the $C R$ of $P$. maxima remained steady $\left(Q_{10}=1.02\right)$. In comparing mean $C R$ values of the 2 species at each of the 4 test temperatures, $P$, maxima had a significantly lower CR at $19^{\circ} \mathrm{C}$ than $P$. margaritifera (Table 3 ; ANOVA, $p<0.001$ ). Low temperature, therefore, strongly affected CR in both pearl oyster species, especially in $P$. maxima.

Increased temperature significantly increased $a b$ sorption efficiency (ae) (Fig. 2, Table $1 ; p<0.05$ ) and ae differed significantly between the 2 species $(p<0.05)$. Pinctada maxima had significantly higher mean ae at $32^{\circ} \mathrm{C}$ compared with that at $19^{\circ} \mathrm{C}$ (Table $1, \mathrm{p}<0.05$ ). Its ae increased from 47 to $57 \%$ over the 19 to $32^{\circ} \mathrm{C}$ range. The ae of $P$. margaritifera increased marginally over this temperature range.

Because CR (Fig. 1) and ae (Fig. 2) both generally increased with temperature, especially in Pinctada maxima, this resulted in increasing absorbed energy (AE) with temperature (Fig. 3). $Q_{10}$ values for AE were high over 19 to $23^{\circ} \mathrm{C}$, being 3.24 for $P$. margaritifera and 9.10 for $P$. maxima (Table 2), as AE changed markedly over this range. Mean AE values for both

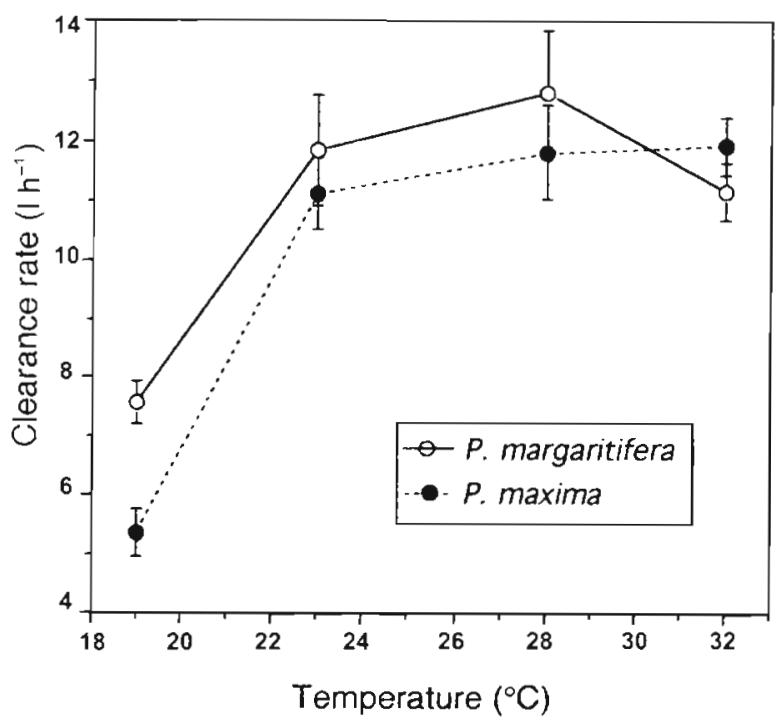

Fig. 1. Clearance rates of Pinctada margaritifera and P. maxima feeding on Isochrysis aff. galbana Tahitian (ca 5000 cells $\mathrm{ml}^{-1}$ ) as a function of acclimatisation temperature

species were significantly different between 19 and $23^{\circ} \mathrm{C}$ (Table $1, \mathrm{p}<0.05$ ). AE of $P$. margaritifera declined distinctly (but not significantly) over the 28 to $32^{\circ} \mathrm{C}$ range, with a low $Q_{10}$ of 0.68 (Table 2). Temperature, therefore, strongly affected $\mathrm{AE}$ in both pearl oyster species, but $P$. maxima was more affected in the lower part and $P$. margaritifera in the upper part of this temperature range

\section{Respiration rate}

Temperature had a highly significant effect on respiration rate $(R)$ and hence on respired energy (RE) in the pearl oysters (Fig. 4, Table $1 ; \mathrm{p}<0.0001$ ). There was also a highly significant difference in the effect of temperature on the R and RE of the 2 oyster species. Mean values increased markedly over the 19 to $23^{\circ} \mathrm{C}$ range in both species, with $Q_{10}$ values for $R E$ of 3.38 for $P$. margaritifera and 4.49 for $P$. maxima (Table 2).

Table 1. Summary of 2-factor ANOVA showing effects of acclimatisation temperature and pearl oyster species (Pinctada margaritifera and $P$. maxima) and their interaction on clearance rate (CR), absorption efficiency (ae), absorbed energy (AE), respiration energy (RE), the value of $(A E-R E)$ and excreted energy (EE). Significant levels are expressed as: ns = not significant $(p>$ $0.05),{ }^{\prime}=p<0.05, \cdots=p<0.001$

\begin{tabular}{|c|c|c|c|c|c|c|c|c|c|c|c|c|}
\hline \multirow{2}{*}{ Source of variation } & \multicolumn{2}{|c|}{$\mathrm{CR}$} & \multicolumn{2}{|c|}{ ae } & \multicolumn{2}{|c|}{$\mathrm{AE}$} & \multicolumn{2}{|c|}{ RE } & \multicolumn{2}{|c|}{$\mathrm{AE}-\mathrm{RE}$} & \multicolumn{2}{|c|}{$\mathrm{EE}$} \\
\hline & $F$ & $\mathrm{p}$ & $F$ & $\mathrm{p}$ & $F$ & $\mathrm{p}$ & $F$ & $\mathrm{p}$ & $F$ & $\mathrm{p}$ & $F$ & $\mathrm{p}$ \\
\hline Temperature & 30.99 & $\cdots$ & 3.04 & - & 25.4 & $\cdots$ & 19.7 & $\cdots$ & 10.3 & $\cdots$ & 28.3 & $\cdots$ \\
\hline Species & 2.66 & ns & 6.59 & - & 0.51 & ns & 20.4 & $\cdots$ & 5.16 & $\cdot$ & 4.07 & $\cdot$ \\
\hline Interaction & 1.61 & ns & 0.57 & ns & 2.03 & ns & 2.29 & ns & 2.98 & $\cdot$ & 0.60 & ns \\
\hline
\end{tabular}


Table 2. Temperature coefficients $\left(Q_{10}\right)$ for clearance rate (CR) absorbed energy (AE), respired energy (RE), and excreted energy (EE) for Pinctada margaritifera and P. maxima and temperature ranges between 4 acclimatisation temperatures. Results of Tukey tests between these physiological rates and absorption efficiency (ae) and the (AE - RE) value at the 2 temperatures of each range are expressed as: ns = not significant $(p>0.05),{ }^{\bullet}=p<0.05,{ }^{\cdots}=p<0.01, \cdots=p<0.001$

\begin{tabular}{|c|c|c|c|c|}
\hline $\begin{array}{l}\text { Para- } \\
\text { meter }\end{array}$ & Species & $19-23^{\circ} \mathrm{C}$ & $\begin{array}{c}Q_{10} \\
23-28^{\circ} \mathrm{C}\end{array}$ & $28-32^{\circ} \mathrm{C}$ \\
\hline \multirow[t]{2}{*}{ CR } & P. margaritifera & $3.39^{\circ}$ & $1.17^{\mathrm{ns}}$ & $0.71^{\mathrm{ns}}$ \\
\hline & P. maxima & $6.19 \cdots$ & $1.13^{\mathrm{ns}}$ & $1.02^{\mathrm{ns}}$ \\
\hline \multirow[t]{2}{*}{ ae } & P. margaritifera & ns & ns & ns \\
\hline & P. maxima & ns & ns & ns \\
\hline \multirow[t]{2}{*}{$\mathrm{AE}$} & P. margaritifera & $3.24^{\circ}$ & $1.49^{\text {ns }}$ & $0.68^{\mathrm{ns}}$ \\
\hline & P. maxima & $9.10 \cdots$ & $1.34^{\text {ns }}$ & $1.00^{\mathrm{ns}}$ \\
\hline \multirow[t]{2}{*}{ RE } & P. margaritifera & $3.38 \cdots$ & $1.12^{\mathrm{ns}}$ & $2.10^{\circ}$ \\
\hline & P. maxima & $4.49^{\cdots}$ & $1.09^{\text {ns }}$ & $1.08^{\mathrm{ns}}$ \\
\hline \multirow[t]{2}{*}{$\mathrm{AE}-\mathrm{RE}$} & P. margaritifera & • & ns & ns \\
\hline & $P$ maxima & $\cdots$ & ns & ns \\
\hline \multirow[t]{2}{*}{ EE } & P. margaritifera & $2.02^{\text {ns }}$ & $1.27^{\text {ns }}$ & $2.47^{\circ}$ \\
\hline & P. maxima & $1.48^{\mathrm{ns}}$ & $1.65^{\mathrm{ns}}$ & $2.62 \cdots$ \\
\hline
\end{tabular}

Above $23^{\circ} \mathrm{C}, \mathrm{RE}$ in $P$. maxima tended to plateau with $Q_{10}$ values near 1 , while $P$. margaritifera increased abruptly from 28 to $32^{\circ} \mathrm{C}$. Thus, mean RE of $P$. maxima at $19^{\circ} \mathrm{C}$ was significantly lower than RE at all other temperatures, but other RE values did not differ significantly (Table 2). Mean RE values for $P$. margaritifera were all significantly different except at 23 and $28^{\circ} \mathrm{C}$. Temperature, therefore, affected $\mathrm{R}$ in both pearl oyster

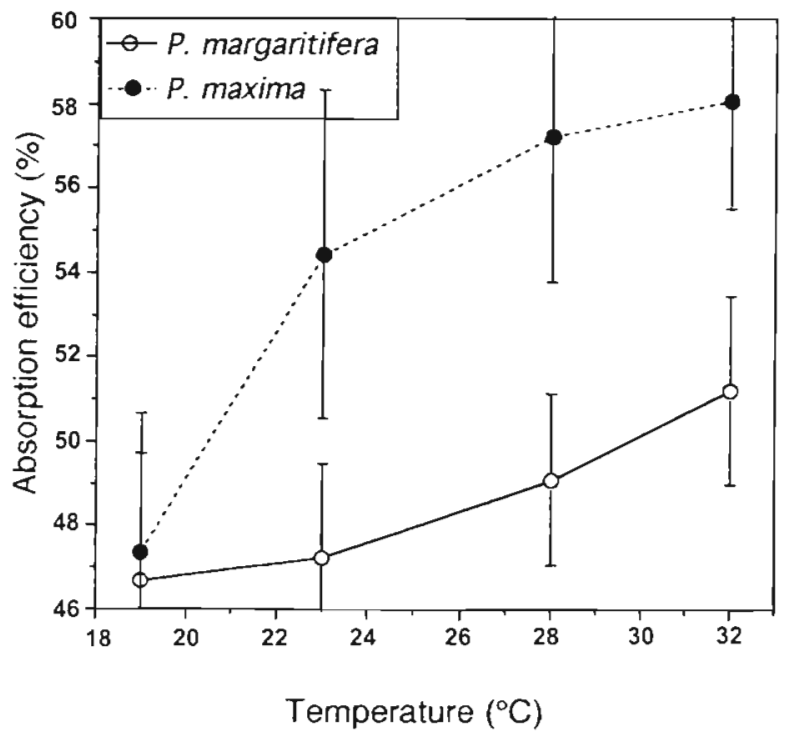

Fig. 2. Absorption efficiencies of Pinctada margaritifera and P. maxima feeding on Isochrysis aff. galbana Tahitian (ca 5000 cells $\mathrm{ml}^{-1}$ ) as a function of acclimatisation temperature
Table 3. Summary of interspecific comparisons between Pinctada margaritifera and $P$. maxima for mean values of clearance rate (CR), absorption efficiency (ae), absorbed energy $(A E)$, respired energy (RE), the (AE - RE) value and excreted energy $(E E)$ at 4 acclimatisation temperatures. ns = not significant $(p>0.05), \cdot=p<0.05, \cdots=p<0.01, \cdots=p<0.001$ (1-way ANOVAs)

\begin{tabular}{|lcccc|}
\hline \multirow{2}{*}{ Parameter } & \multicolumn{4}{c}{ Temperature $\left({ }^{\circ} \mathrm{C}\right)$} \\
& 19 & 23 & 28 & 32 \\
\hline $\mathrm{CR}$ & $\cdots$ & $\mathrm{ns}$ & $\mathrm{ns}$ & $\mathrm{ns}$ \\
$\mathrm{ae}$ & $\mathrm{ns}$ & $\mathrm{ns}$ & $\cdot$ & $\cdot$ \\
$\mathrm{AE}$ & $\cdot$ & $\mathrm{ns}$ & ns & $\cdot$ \\
$\mathrm{RE}$ & $\mathrm{ns}$ & $\mathrm{ns}$ & ns & $\cdots$ \\
$\mathrm{AE}-\mathrm{RE}$ & $\cdot$ & ns & ns & $\cdot$ \\
$\mathrm{EE}$ & ns & ns & ns & $\cdot$ \\
\hline
\end{tabular}

species at low parts of the temperature range and $P$. margaritifera was also affected at the higher end of the range.

\section{Excretion rate}

There were significant effects of temperature on ammonia excretion rate (E) and hence excreted energy (EE) (Fig. 5, Table 1; p $<0.0001$ ). Mean EE values of Pinctada margaritifera and $P$. maxima differed significantly between 28 and $32^{\circ} \mathrm{C}$ (Fig. 5 , Table 2, $\mathrm{p}<0.01$ ). For these species the highest $Q_{10}$ value was in the 28 to $32^{\circ} \mathrm{C}$ interval: 2.47 for $P$. mar-

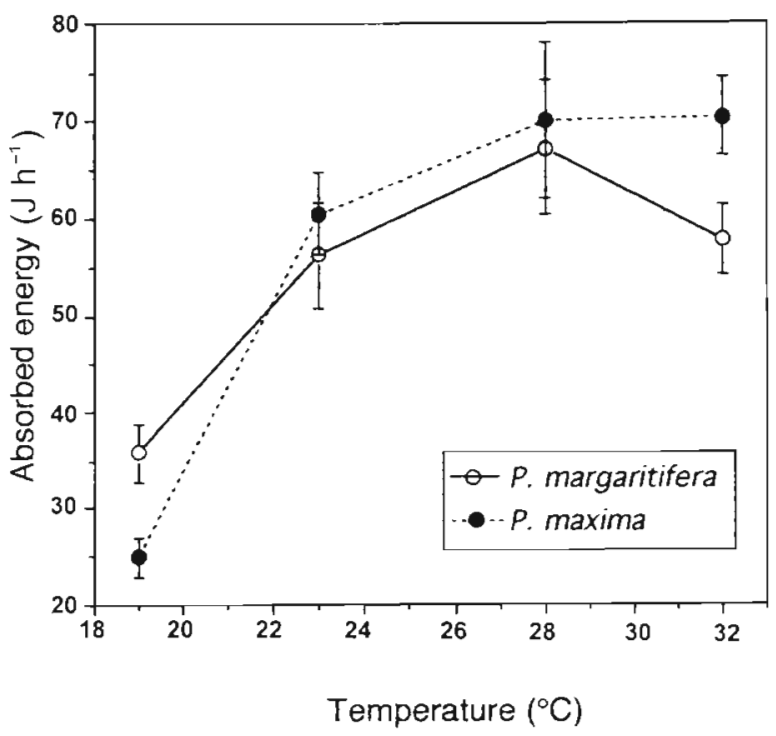

Fig. 3. Absorbed energy of Pinctada margaritifera and $P$. maxima feeding on Isochrysis aff. galbana Tahitian (ca 5000 cells $\mathrm{ml}^{-1}$ ) as a function of acclimatisation temperature 


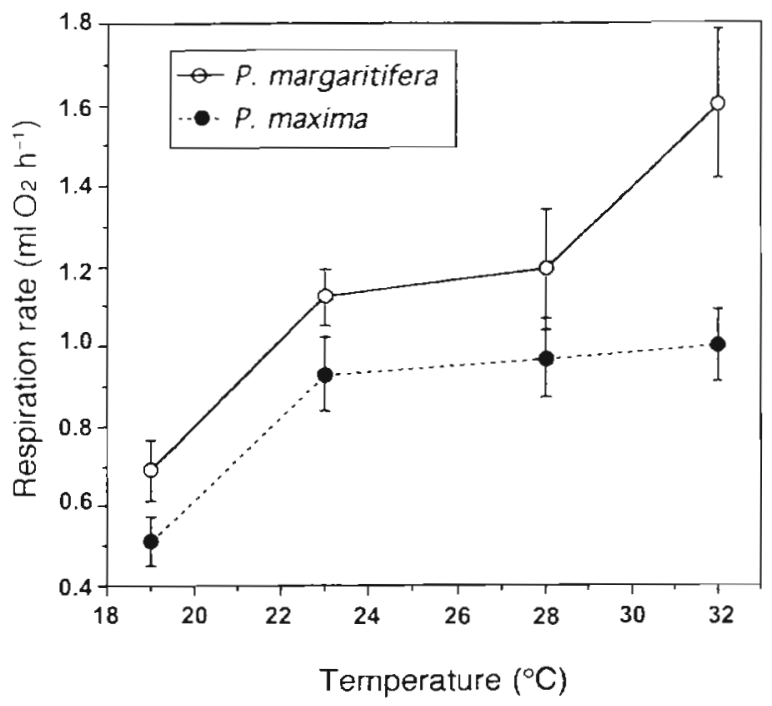

Fig. 4. Respiration rates of Pinctada margaritifera and $P$. maxima feeding on Isochrysis aff. galbana Tahitian (ca 5000 cells $\mathrm{ml}^{-1}$ ) as a function of acclimatisation temperature

garitifera and 2.62 for P. maxima (Table 2). P. maxima had significantly higher EE than $P$. margaritifera at $32^{\circ} \mathrm{C}$ (Table 3, $\mathrm{p}<0.05$ ). Thus, temperature affected ammonia excretion of both species, especially at the higher temperatures.

\section{Scope for Growth}

There were significant effects of temperature and species (and interactions) on the (AE - RE) value (Table 1). Mean (AE - RE) values of Pinctada margaritifera and P. maxima were significantly different between 19 and $23^{\circ} \mathrm{C}$ (Table 1). Tables $3 \& 4$ show that at $19^{\circ} \mathrm{C} P$. margaritifera had a significantly higher (AE - RE) value than $P$. maxima while at $32^{\circ} \mathrm{C} P$. maxima had a significantly higher (AE - RE) value. There were no significant interspecific differences at 23 and $28^{\circ} \mathrm{C}$.

Scope for Growth (SFG) is presented for both species of pearl oysters in Table 4. RE is an important component of the energy budget of the pearl oysters, being 32 to $56 \%$ of AE for Pinctada margaritifera and 29 to $49 \%$ for $P$. maxima. By comparison, EE represents a small proportion of the energy budget of both species, being only 2 to $5 \%$ of AE.

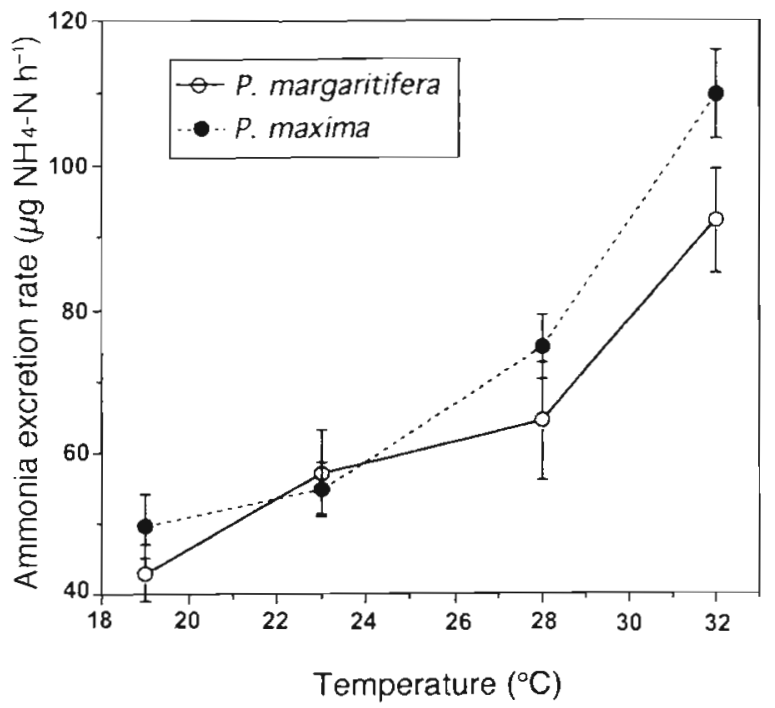

Fig. 5. Excretion rates of Pinctada margaritifera and $P$. maxima feeding on Isochrysis aff. galbana Tahitian (ca 5000 cells $\mathrm{ml}^{-1}$ ) as a function of acclimatisation temperature

Table 4 indicates that both species had greatest SFG at $28^{\circ} \mathrm{C}$. SFG of Pinctada maxima was most affected by low temperature $\left(19^{\circ} \mathrm{C}\right)$, whereas low and high temperatures $\left(19\right.$ and $\left.32^{\circ} \mathrm{C}\right)$ affected SFG of $P$, margaritifera. Following from the results of statistical comparisons in Table 1, there were no significant intraspecific differences in $\mathrm{SFG}$ values at the intermediate temperatures, 23 and $28^{\circ} \mathrm{C}$. This is due to the lack of significant differences between both the (AE - RE) and $\mathrm{EE}$

Table 4. Summary of absorbed energy ( $A E$ ), respired energy ( $R E$ ), the ( $A E-R E$ ) value, excreted energy ( $E E$ ), resultant ( $\mathrm{AE}$ - RE) and Scope For Growth (SFG = (AE - RE) - EE, $\mathrm{J} \mathrm{h}^{-1}$ ) for Pinctada margaritifera and $P$. maxima at 4 acclimatisation temperatures. Values of (AE - RE) were calculated from individual oysters. The data are standardised to $1 \mathrm{~g}$ dry tissue wt in size. $95 \%$ confidence limits of mean ( $A E-R E)$ and EE values are also shown

\begin{tabular}{|lcccc|}
\hline Parameter $\left(\mathrm{J} \mathrm{h}^{-1}\right)$ & \multicolumn{5}{c}{ Temperature $\left({ }^{\circ} \mathrm{C}\right)$} \\
& 19 & 2.3 & 28 & 32 \\
\hline AE & & & & \\
$P$. margaritifera & 35.8 & 55.1 & 67.3 & 57.7 \\
$\quad$. maxima & 25.0 & 60.5 & 70.1 & 70.0 \\
RE & & & & \\
$P$. margaritifera & 14.0 & 22.8 & 24.2 & 32.5 \\
$\quad$. maxima & 10.4 & 18.9 & 19.7 & 20.4 \\
AE - RE & & & & \\
$P$. margaritifera & $21.8 \pm 4.9$ & $32.2 \pm 8.2$ & $43.1 \pm 18.2$ & $25.2 \pm 10.6$ \\
P. maxima & $14.6 \pm 3.5$ & $41.6 \pm 10.7$ & $50.5 \pm 18.5$ & $49.5 \pm 8.8$ \\
EE & & & & \\
$P$. margaritifera & $1.1 \pm 0.3$ & $1.4 \pm 0.4$ & $1.6 \pm 0.5$ & $2.3 \pm 0.4$ \\
$P$. maxima & $1.2 \pm 0.3$ & $1.5 \pm 0.3$ & $1.9 \pm 0.3$ & $2.7 \pm 0.4$ \\
SFG = (AE - RE) - EE & & & & \\
$P$. margaritifera & 20.7 & 30.8 & 41.5 & 22.9 \\
P. maxima & 13.4 & 40.1 & 48.6 & 46.8 \\
\hline
\end{tabular}


values at these temperatures. SFG in both species at $19^{\circ} \mathrm{C}$ was significantly lower than at $23^{\circ} \mathrm{C}$, due to the significantly lower ( $\mathrm{AE}-\mathrm{RE}$ ) values at $19^{\circ} \mathrm{C}$ compared to $23^{\circ} \mathrm{C}$ and no significant difference in $\mathrm{EE}$

Pinctada margaritifera had significantly higher SFG than P. maxima at $19^{\circ} \mathrm{C}$. This is because at $19^{\circ} \mathrm{C}$ the 2 species expended the same amounts of RE and EE, but $P$. margaritifera absorbed more energy (Fig. 3). There was no significant difference between the species in SFG at 23 and $28^{\circ} \mathrm{C}$ : Table 3 shows lack of significant difference for both the (AE - RE) values and $E E$ at these temperatures. $P$. maxima had significantly higher SFG than P. margaritifera at $32^{\circ} \mathrm{C}$ (Table 4). These interspecific differences were mainly due to the lower CR of $P$. maxima at $19^{\circ} \mathrm{C}$ and the higher oxygen consumption of P. margaritifera at $32^{\circ} \mathrm{C}$ (Figs. 1 \& 4, Table 3 ).

\section{DISCUSSION}

\section{Physiological processes}

As briefly considered in the 'Introduction', the metabolic rate of bivalve molluscs (and other poikilothermic organisms) usually increases with increasing temperature up to a maximum, above which it decreases (e.g. Shumway 1982, Bodoy et al. 1986). This peak and decline in metabolic rate are related to the balance between 2 opposing effects of increasing temperature: increasing the rate of chemical reactions versus greater denaturation of the enzymes that catalyse them. Thus, Uemoto (1968) found that respiration rate (R) of Pinctada fucata martensii increased up to ca $27^{\circ} \mathrm{C}$ and then decreased (range tested: 13 to $33^{\circ} \mathrm{C}$ ). Sugiyama \& Tomori (1988) demonstrated that the turning point for $\mathrm{R}$ of $P$. margaritifera occurred at ca $33^{\circ} \mathrm{C}$ (range tested: 15 to $35^{\circ} \mathrm{C}$ ). Although $\mathrm{R}$ of $P$. margaritifera and $P$. maxima was profoundly influenced by temperature, such turning points were not found in this study (Fig. 4). This is probably because the upper temperature tested $\left(32^{\circ} \mathrm{C}\right)$ was not sufficiently near the upper lethal temperature (e.g. Sugiyama \& Tomori 1988). However, another important factor is that pearl oysters in this study were tested at their acclimatisation temperatures, not by acute temperature exposures as in the other pearl oyster studies. The $\mathrm{R}$ versus temperature relationships measured in this study are more likely to reflect these relationships for animals under normal field conditions compared to acute temperature exposures.

Filtration in suspension-feeding bivalves also generally increases with water temperature up to an optimum temperature, above which it declines (reviews by Winter 1978 and Griffiths \& Griffiths 1987). Miyauchi (1962) and Numaguchi (1994) found that the maximum clearance rate (CR) of Pinctada fucata martensii occurred in the approximate range of 24 to $28^{\circ} \mathrm{C}$. In this study, significant increases in CR of $P$. margaritifera and $P$. maxima with temperature were shown over the temperature range 19 to $23^{\circ} \mathrm{C}$ and over the studied range, 19 to $32^{\circ} \mathrm{C}$ (Table 1 ). There was a clear maximum CR for $P$. margaritifera in the vicinity of $28^{\circ} \mathrm{C}$, but no maximum for $P$. maxima up to $32^{\circ} \mathrm{C}$

Kinne (1971) described how marine invertebrates have the capacity to modify their response to temperature through acclimatisation (or acclimation in the laboratory) so that they increase their capacity to survive, reproduce or compete under new conditions. Temperate suspension-feeding molluscs, such as the gastropod Crepidula fornicata (Newell \& Kofoed 1977) and the bivalves Mytilus edulis (Widdows \& Bayne 1971, Bayne et al. 1976b) and Ostrea edulis (Buxton et al. 1981), acclimate to temperature in such a way that physiological processes like clearance and respiration are maintained relatively independent of temperature. Thus they maintain high levels of energy balance over broad temperature ranges. CR and $\mathrm{R}$ of Pinctada margaritifera and $P$. maxima were relatively independent of temperature over the ranges 23 to $28^{\circ} \mathrm{C}$ and 23 to $32^{\circ} \mathrm{C}$, respectively. The relatively constant levels of CR and $\mathrm{R}$ over 5 and $9^{\circ} \mathrm{C}$ temperature ranges for the pearl oysters of this study are probably examples of compensation though acclimatisation, although they do not occur over wide temperature ranges. Scope for Growth (SFG) of $P$. margaritifera and $P$. maxima was similarly maintained at relatively high levels at 23 to $28^{\circ} \mathrm{C}$ and 23 to $32^{\circ} \mathrm{C}$, respectively (Table 4 ). Thus it seems that these pearl oysters are capable of seasonal acclimatisation over moderate ranges of warm temperatures.

The effect of temperature on absorption efficiency (ae) in bivalve molluscs is inconsistent, according to the data available. Temperature was found to have little effect on ae in Ostrea edulis (Buxton et al. 1981, Hutchinson \& Hawkins 1992), although this was contradicted by Beiras et al. (1995). It had little effect in 5 mussel species (Wilbur \& Hilbish 1989, van Erkom Schurink \& Griffiths 1992). By contrast, temperature had a positive effect on ae in Arctica islandica and Modiolus modiolus (Winter 1969, 1977) and spat of Venerupis pullastra (Albentosa et al. 1994). Similarly, results varied in the 2 Pinctada species, where ae of $P$. margaritifera was not influenced by temperature (Fig. 2, Table 1), while $P$. maxima showed a significant increase in ae from 19 to $32^{\circ} \mathrm{C}$ (Table 1 ). There is some evidence that these temperature effects are the result of changes in enzymatic processes. Seiderer \& Newell (1979) demonstrated that activity of $\alpha$-amylase extracted from the crystalline style of the mussel Choromytilus meridionalis was enhanced following warm acclimation. Albentosa et al. (1994) described enhanced 
enzymatic activity in $V$. pullastra and suggested that it may form an integral part of the increase in absorbed energy ( $\mathrm{AE}$ ) at high temperatures and offset increased metabolic losses. It may be postulated that such a temperature acclimation effect on digestive enzymes caused the increased ae for P. maxima, but this would ignore the lack of effect in $P$. margaritifera.

The temperature coefficients $\left(Q_{10}\right)$ for ammonia excretion rates (E) by Pinctada margaritifera and $P$. maxima were in the range of 1.3 to 2.6 , with the highest values in the high temperature interval. They were neither as high nor as low as the extreme $Q_{10}$ values for other parameters. Similar $Q_{10}$ values of approximately 2 have been obtained from temperate bivalves: Mytilus edulis (Bayne \& Scullard 1977), Tapes japonica (Mann \& Glomb 1978), Geukensia demissa (Wilbur \& Hilbish 1989), Venerupis pullastra (Albentosa et al. 1994), and Ostrea edulis (Beiras et al. 1995). It seems that while E is significantly influenced by temperature, the influence is not as great as for other parameters. P. fucata martensii, with a $Q_{10}$ value for $\mathrm{E}$ of $3.1\left(16\right.$ to $\left.28^{\circ} \mathrm{C}\right)$ (Itoh 1976), has among the higher values recorded.

The ratio between oxygen consumed and nitrogen excreted ( $\mathrm{O}: \mathrm{N}$ ratio) has been used as an index of stress and protein catabolism in bivalves (Bayne et al. 1985). Low values, reflecting relatively high rates of nitrogen excretion, indicate stress and protein catabolism. High $\mathrm{O}: \mathrm{N}$ ratios that have been recorded for bivalve molluscs are 52.8, ca 47 and ca 35 for Modiolus modiolus (Navarro \& Thompson 1996), Mytilus edulis (Widdows 1978) and Ostrea edulis (Beiras et al. 1995), respectively. Considerably lower O:N values for these species have been recorded at stressful temperatures, e.g. 11.4, ca 22 and ca 10, respectively. In comparison, O:N ratios for the pearl oysters were all low: 20.1 to 24.7 for Pinctada margaritifera and 11.4 to 20.0 for $P$. maxima. Highest $\mathrm{O}: \mathrm{N}$ values for both species were at $23^{\circ} \mathrm{C}$ (Table 5). Such relatively low values in the pearl oysters cannot all be attributed to unfavourable temperatures or apparently to stress. They are not attribut-

Table 5. Respiration:excretion ratios (O:N ratio) and filtration efficiencies (= clearance rate to respiration rate ratio, $1 \mathrm{ml}^{-1}$ $\mathrm{O}_{2}$ ) of Pinctada margaritifera and $P$. maxima at 4 acclimatisation temperatures

\begin{tabular}{|lcccr|}
\hline & \multicolumn{5}{c|}{ Temperature $\left({ }^{\circ} \mathrm{C}\right)$} \\
& 19 & 23 & 28 & 32 \\
\hline O:N ratio & & & & \\
$\begin{array}{l}\text { P. margaritifera } \\
\text { P. maxima }\end{array}$ & 20.1 & 24.7 & 23.1 & 21.7 \\
Filtration efficiency & 12.8 & 20.0 & 16.2 & 11.4 \\
$\begin{array}{l}\text { P. margaritifera } \\
\text { P. maxima }\end{array}$ & 11.0 & 10.6 & 10.8 & 7.0 \\
& 10.5 & 12.0 & 12.2 & 12.6 \\
\hline
\end{tabular}

able to low $\mathrm{R}$, but rather to systematically high $\mathrm{E}$ (Yukinira et al. 1998a, Table 5), which may be a characteristic of these species. It is possible that these relatively high levels of ammonia excretion are related to $\mathrm{N}$ coming from the diet, rather than to $\mathrm{N}$ arising from tissue protein catabolism.

The ratio of the volume of water cleared per volume of oxygen consumed (CR:R, l water $\left.\mathrm{ml}^{-1} \mathrm{O}_{2}\right)$ is used as an index of filtration efficiency (Newell et al. 1977, Newell \& Branch 1980). The CR:R ratios for Pinctada margaritifera and P. maxima were 7.0 to 11.0 and 10.5 to 12.6 for $1 \mathrm{~g}$ tissue weight animals, respectively (Table 5). They were essentially unaffected by temperature, except for a decrease in P. margaritifera at $32^{\circ} \mathrm{C}$. Ostrea edulis had maximum filtration efficiency (ca 3.3) at $20^{\circ} \mathrm{C}$, and its lowest efficiency $(0.3)$ at $10^{\circ} \mathrm{C}$ (Newell et al. 1977). The suspension-feeding gastropod Crepidula fornicata had its highest value (ca 2.7) at 19 and $25^{\circ} \mathrm{C}$, and its lowest (ca 1.4 ) at $10^{\circ} \mathrm{C}$ (Newell $\&$ Kofoed 1977). Thus, on the basis of these very limited comparative data, $P$. margaritifera and $P$. maxima are relatively efficient suspension feeders, in terms of energy cost

\section{Geographic distributions}

Considering together the results for SFG, O:N ratio and filtration efficiency, the optimum temperatures for Pinctada margaritifera and P. maxima are approximately 23 to $28^{\circ} \mathrm{C}$ and 23 to $32^{\circ} \mathrm{C}$, respectively. Thus both $P$. margaritifera and $P$. maxima are well adapted to the temperature range 23 to $28^{\circ} \mathrm{C}$. However, poor physiological performance was observed for $P$. maxima at $19^{\circ} \mathrm{C}$ and for $P$. margaritifera at $32^{\circ} \mathrm{C}$ (Tables $4 \& 5$ ). These results help to explain why the former species is less able than $P$. margaritifera to extend its geographic distribution to higher latitudes

An excellent example of the application of ecophysiology and energetics to explain geographic distribution in bivalves is the study by van Erkom Schurink \& Griffiths (1992). They related physiological rates and SFG of 4 South African mussels - Choromytilus meridionalis, Mytilus galloprovincialis, Aulacomya ater and Perna perna - to their distribution patterns along the South African coast. A. ater and C. meridionalis, which attain maximum densities along the cool temperate west coast of South Africa, had maximum SFGs at $10^{\circ} \mathrm{C}$. P. perna, which is most abundant along the subtropical east coast, had highest SFG at $20^{\circ} \mathrm{C}$. M. galloprovincialis maintained high levels of SFG across the whole temperature range $\left(10\right.$ to $\left.20^{\circ} \mathrm{C}\right)$. Since $\mathrm{M}$. galloprovincialis was newly introduced to the cool west coast, the authors predicted that this species was likely to spread rapidly into warmer coastal regions. 
Pass et al. (1987) found that the greatest mortality of Pinctada maxima following transportation of oysters between collection sites occurred when the water temperature was lowest (ca $19^{\circ} \mathrm{C}$ ). They found that $P$. $\max$ ima was more susceptible to disease at $19^{\circ} \mathrm{C}$ compared to $29^{\circ} \mathrm{C}$. These results are in accord with the low rates of feeding, physiological parameters and SFG at $19^{\circ} \mathrm{C}$. Clearly $19^{\circ} \mathrm{C}$ is a marginal temperature for this species.

On the other hand, $32^{\circ} \mathrm{C}$ adversely influenced Pinctada margaritifera in terms of feeding and SFG; yet this species is distributed through the same low-latitude, high-temperature region as $P$. maxima. A difference between these species is that $P$. maxima is farmed at these low latitudes while $P$. margaritifera is farmed at higher latitudes. Both species occur in low latitudes, but our physiological data support the empirical evidence of industry, that $P$. maxima is better suited for culture in these conditions.

\section{Aquaculture}

The rates of suspension feeding of Pinctada margaritifera and $P$. maxima are relatively and absolutely high compared with other suspension-feeding bivalves (Yukihira et al. 1998a, Pouvreau et al. 1999). The present study demonstrates that these high feeding rates are maintained over a substantial part of the temperature ranges occurring in their natural habitats. Therefore, their ecological roles in energy transfer and environmental impacts on ecosystems as suspension feeders can be of considerable importance. This is relevant to pearl culture, because there may be extremely high densities of pearl oysters within farm areas. The low levels of particulate food sources in some ecosystems, such as in coral reef waters, will be unable to support the grazing pressure of large numbers of pearl oysters. Dense pearl oyster culture has the potential to exceed the available energy (particulate food sources) in ecosystems where there are low water replacement rates (Vacelet et al. 1996, Yukihira et al. 1998a)

The relationships between physiological parameters and temperature allow us to predict the optimal temperature regimes for culture of these pearl oysters. They are 23 to 28 and 23 to $32^{\circ} \mathrm{C}$ for Pinctada margaritifera and $P$. maxima, respectively, provided other environmental parameters, such as food and silt levels (Yukihira et al. 1998b, 1999) are favourable.

Acknowledgements. We thank Mr Michael Crimp of Indian Pacific Pearls for providing some of the experimental animals. We are also grateful to Dr David McKinnon of AIMS for his assistance with use of the particle counter. This research was funded by an Internal Research Allowance and Meritorious Research Grant from James Cook University.

\section{LITERATURE CITED}

Albentosa M, Beiras R, Pérez Camacho A (1994) Determination of optimal thermal conditions for growth of clam (Venerupis pullastra) seed. Aquaculture 126:315-328

Bayne BL, Newell RC (1983) Physiological energetics of marine molluscs. In: Saleuddin ASM, Wilbur KM (eds) The Mollusca, Vol 4, Physiology, Part 1. Academic Press, New York, p 407-515

Bayne BL, Scullard C (1977) Rates of nitrogen excretion by species of Mytilus (Bivalvia: Mollusca). J Mar Biol Assoc UK 57:355-369

Bayne BL, Thompson RJ, Widdows J (1976a) Physiology. 1. In: Bayne BL (ed) Marine mussels their ecology and physiology. Cambridge University Press, Cambridge, p $121-206$

Bayne BL, Bayne CJ, Carefoot TC, Thompson RJ (1976b) The physiological ecology of Mytilus californianus Conrad. 1. Metabolism and energy balance. Oecologia 22:211-228

Bayne BL, Brown DA, Burns $K$, Dixon DR, Ivanovici $A$, Livingstone DR, Lowe DM, Moore MN, Stebbing ARD, Widdows $J$ (1985) The effects of stress and pollution on marine animals. Chapters 1, Physiological measurements, and 7, Physiological procedures. Praeger Press, New York, p $3-45,161-178$

Beiras R, Pérez Camacho A, Albentosa M (1995) Short-term and long-term alterations in the energy budget of young oyster Ostrea edulis L. in response to temperature change. J Exp Mar Biol Ecol 186:221-236

Bodoy A, Riva A, Maitre-Allain T (1986) Comparaison de la respiration chez Ruditapes decussatus (L) et $R$. philippinarum (Adams \& Reeve) en fonction de la temperature. Vie Milieu 36:83-89

Buxton CD, Newell RC, Field JG (1981) Response-surface analysis of the combined effects of exposure and acclimation temperatures on filtration oxygen consumption and scope for growth in the oyster Ostrea edulis. Mar Ecol Prog Ser 6:73-82

Coeroli M, De Gaillande D, Landret JP, Coatanea D (1984) Recent innovations in cultivation of molluscs in French Polynesia. Aquaculture 39:45-67

Conover RJ (1966) Assimilation of organic matter by zooplankton. Limnol Oceanogr 18:673-678

Gervis $\mathrm{MH}_{1}$ Sims NA (1992) The biology and culture of pearl oysters (Bivalvia: Pteriidae). ICLARM Stud Rev 21, ICLARM, Manila

Griffiths CL, Griffiths RJ (1987) Bivalvia. In: Pandian TJ, Vernberg FJ (eds) Animal energetics, Vol 2. Bivalvia through Reptilia. Academic Press, New York, p 1-87

Hildreth DI, Crisp DJ (1976) A corrected formula for calculation of filtration rate of bivalve molluscs in an experimental flowing system. J Mar Biol Assoc UK 56:111-120

Hutchinson S, Hawkins LE (1992) Quantification of the physiological responses of the European flat oyster Ostrea edulis L. to temperature and salinity. J Molluscan Stud 8: $215-226$

Hynd JS (1955) A revision of Australian pearl-shells, genus Pinctada (Lamellibranchia). Aust J Mar Freshw Res 6: $98-137$

Itoh K (1976) Relations of oxygen consumption and ammonia nitrogen excreted to body size and to water temperature in the adult of pearl oyster Pinctada fucata. Bull Natl Pearl Res Lab 20:2254-2275 (in Japanese)

Kinne O (1971) Temperature. 3.3 Animals. 3.3.1 Invertebrates. In: Kinne O (ed) Marine ecology, Vol 1, Environmental factors, Part 1. Wiley-Interscience, London, p $407-514$ 
Kobayashi S, Tobata M (1949) Studies on culture of pearl. II. Activity of pearl oyster in winter. Bull Jpn Soc Sci Fish 14: 196-199 (in Japanese)

Mann R, Glomb SJ (1978) The effect of temperature on growth and ammonia excretion of the Manila clam Tapes japonica. Estuar Coast Mar Sci 6:335-339

Mivauchi T (1962) Clearance rate of the pearl oyster Pinctada fucata martensii. II. Effects of temperature and salinity. Suisan Zoshoku 10:73 (in Japanese)

Navarro JM, Thompson RJ (1996) Physiological energetics of the horse mussel Modiolus madiolus in a cold ocean envi ronment. Mar Ecol Prog Ser 138:135-148

Newell RC, Branch GM (1980) The influence of temperature on the maintenance of metabolic energy balance in marine invertebrates. Adv Mar Biol 17:329-396

Newell RC, Kofoed LH (1977) Adjustment of the components of energy balance in the gastropod Crepidula fornicata in response to thermal acclimation. Mar Biol 44:275-286

Newell RC, Johnson LG, Kofoed LH (1977) Adjustment of the components of energy balance in response to temperature change in Ostrea edulis. Oecologia 30:97-110

Numaguchi K (1994) Effect of water temperature on the filtration rate of Japanese pearl oyster Pinctada fucata martensii. Suisan Zoshoku 41:1-6 (in Japanese)

Numaguchi K, Tanaka Y (1986) Effects of temperature on mortality and growth of the spat of the pearl oyster, Pinctada fucata martensii. Bull Natl Res Inst Aquacult 9:35-39 (in Japanese)

Oliver J, De'Ath G, Done T, Williams D, Furnas M, Moran P (1995) Long-term monitoring of the Great Barrier Reef Australian Institute of Marine Science, Status report, no. 1 AIMS, Townswille

Pass DA, Dybdahl R, Mannion MM (1987) Investigations into the causes of mortality of the pearl oyster, Pinctada maxima (Jameson), in Western Australia. Aquaculture 65: $149-169$

Pouvreau S, Jonquieres G, Buestel D (1999) Filtration by the pearl oyster, Pinctada margaritifera, under conditions of low seston load and small particle size in a tropical lagoon habitat. Aquaculture 176:295-314

Reed W (1966) Cultivation of the black-lip pearl oyster Pinctada margaritifera (L.). J Conchol 26:26-32

Seiderer LJ, Newell RC (1979) Adjustment of the activity of aamylase extracted from the style of the black mussel Choromytilus meridionalis (Krauss) in response to thermal acclimation. J Exp Mar Biol Ecol 39:79-86

Seki M (1972) Studies on natural factors affecting the growth and pearl quality of Japanese pearl oyster Pinctada fucata in culture environments. Bull Mie Pref Fish Res 1:32-149 (in Japanese)

Shumway SE (1982) Oxygen consumption in oysters: an overview. Mar Biol Lett 3:1-23

Sims NA (1993) Size, age and growth of the black-lip pearl oyster, Pinctada margaritifera (L.) (Bivalvia; Pteriidae). J Shellfish Res 12:223-228

Solorzano L (1969) Determination of ammonia in natural

Editorial responsibility: Otto Kinne (Editor),

Oldendorf/Luhe, Germany waters by the pheno-hypochlorite method. Limnol Oceanogr 14:799-801

Sugiy ama A, Tomori A (1988) Oxygen consumption of blacklip pearl oyster. Suisan Zoshoku 36:121-125 (in Japanese)

Uemoto $\mathrm{H}$ (1968) Relationship between oxygen consumption by the pearl oyster and its environmental temperature. Bull Natl Pearl Res Lab 13:1617-1623 (in Japanese)

Vacelet E, Arnoux A, Thomassin B (1996) Particulate material as an indicator of pearl-oyster excess in the Takapoto lagoon (Tuamotu, French Polynesia). Aquaculture 144: $133-148$

van Erkom Schurink C, Griffiths CL (1992) Physiological energetics of four South African mussel species in relation to body size, ration and temperature. Comp Biochem Physiol 101A:779-789

Warren CE, Davis GE, (1967) Laboratory studies on the feeding bioenergetics and growth of fish. In: Gerking SD (ed) The biological basis of freshwater fish production. Blackwell Scientific Publications, Oxford, p 175-214

Widdows J (1978) Physiological indices of stress in Mytilus edulis. J Mar Biol Assoc UK 58:109-124

Widdows J, Bayne BL (1971) Temperature acclimation of Mytilus edulis with reference to its energy budget. $J$ Mar Biol Assoc UK 51:827-843

Wieser W (1973) Temperature relations of ectotherms: a speculative review. In: Wieser W (ed) Effects of temperature on ectothermic organisms. Springer-Verlag, Berlin, p 1-24

Wilbur AE, Hilbish TJ (1989) Physiological energetics of the ribbed mussel Geukensia demissa (Dillwyn) in response to increased temperature. J Exp Mar Biol Ecol 131:161-170

Winter JE (1969) On the influence of food concentration and other factors on filtration rate of food utilization in the mussels Arctica islandica and Modiolus modiolus. Mar Biol 4:87-135

Winter JE (1977) Suspension-feeding in lamellibranchiate bivalves with particular reference to aquaculture. Medio Ambiente 3:48-69

Winter JE (1978) A review on the knowledge of suspensionfeeding in lamellibranchiate bivalves with special reference to artificial aquaculture systems. Aquaculture 13: $1-33$

Yukihira H, Klumpp DW, Lucas JS (1998a) Effects of body size on suspension feeding and energy budgets of the pearl oysters Pinctada margaritifera and P. maxima. Mar Ecol Prog Ser 170:119-130

Yukihira H, Klumpp DW, Lucas JS (1998b) Comparative effects of microalgal species and concentration on suspension feeding and energy budgets of the pearl oysters $P$ inctada margaritifera and P. maxima. Mar Ecol Prog Ser 171: $71-84$

Yukihira H, Klumpp DW, Lucas JS (1999) Feeding adaptations of the pearl oysters Pinctada margaritifera and $P$. maxima to variations in natural particles. Mar Ecol Prog Ser 182:161-173

Zar JH (1996) Biostatistical analysis, 3rd edn. Prentice Hall, Englewood Cliffs, NJ

Submitted: June 24, 1999; Accepted: October 13, 1999

Proofs received from author(s): March 7, 2000 